ISSN: 02162938

\title{
Kemampuan Mengeksplorasi Bahan Bekas pada Mahasiswa PG-PAUD Universitas PGRI Adi Buana Surabaya melalui Project Based Learning
}

Anies Listyowati

${ }^{1}$ PG-PAUD, FKIP, Universitas PGRI Adi Buana Surabaya JI. Dukuh Menanggal XII No.4 Surabaya

\author{
aniespaud@unipasby.ac.id
}

\begin{abstract}
Abstrak: Tujuan penelitian ini adalah untuk mengetahui tingkat kemampuan mengeksplorasi bahan bekas pada mahasiswa PG-PAUD Universitas PGRI Adi Buana Surabaya. Penelitian ini adalah penelitian deskripstif. Kreativitas adalah salah satu syarat mutlak bagi calon guru PAUD. Kemampuan kreativitas dapat diketahui dengan berbagai cara, salah satunya cara mengeksplorasi bahan bekas. Mahasiswa yang sedang menempuh mata kuliah Kreativitas dan Keberbakatan sejumlah 16 anak sebagai subjek penelitian. Setiap subjek mendapatkan project untuk melakukan eksplorasi terhadap satu macam bahan bekas untuk dijadikan tujuh macam produk. Pengumpulan data menggunakan metode observasi dan wawancara. Analisis data dengan cara mengidentifikasi proses berpikir kreatif yang terdiri dari empat tahap yaitu 1) persiapan 2) perenungan 3) penemuan ide 4) verifikasi. Dari hasil observasi dan wawancara dapat diambil kesimpulan bahwa mahasiswa PG-PAUD Universitas PGRI Surabaya menpunyai kreativitas yang cukup mampu dalam mengeksplorasi bahan bekas.
\end{abstract}

Kata Kunci: eksplorasi, bahan bekas, project based learning.

\begin{abstract}
The purpose of this study was to study the level of complexity of the material used in PG-PAUD students at PGRI Adi Buana University Surabaya. This research is descriptive research. Creativity is one of the requirements for prospective PAUD teachers. One way that can be used for used materials. There are 16 students studying creativity and giftedness as research subjects. Each subject gets a project to explore one type of material used to make seven types of products. Data collection uses observation and interview methods. Data analysis by completing the creative thinking process which consists of four sides, namely 1) preparation 2) reflection 3) discovery of ideas 4) verification. From the observations and interviews it can be concluded that PG-PAUD students at the University of PGRI Surabaya have sufficient creativity to explore used materials.
\end{abstract}

Key word: Exploration, Esed Materials, Project Based Learning 


\section{LATAR BELAKANG}

Mahasiswa PG-PAUD sebagai calon pendidik bagi anak-anak usia dini mampu memahami dan menggunakan dengan tepat teori-teori tentang kreativitas karena di dalam pendidikan anak usia dini kreativitas guru menjadi satu kemampuan yang wajib dimiliki oleh setiap guru PAUD. Kreativitas tidak serta merta dapat menjadi sebuah kemampuan apabila tidak mendapatkan sebuah tantangan atau stimulasi. Sebelum memberikan stimulasi yang nantinya akan menjadikan anak kreatif terlebih dahulu guru harus kreatif. Oleh karena itu mahasiswa PG PAUD sebagai calon guru PAUD harus melalui proses berpikir kreatif.

Berpikir kreatif dengan memberikan kebebasan dalam mengeksplorasi ide-ide akan memberikan tantangan bagi mahasiswa. Selain harus kreatif calon guru PAUD juga harus peka terhadap lingkungan. Kreativitas dengan memanfaatkan bahan-bahan bekas yang ada disekelilingnya akan lebih dapat dirasakan kebermanfaatannya secara langsung olehnya. Mahasiswa PG-PAUD akan mendapatkan pengalaman secara langsung bagaimana menjadi penggerak pendidikan yang berkelanjutan. Pengalaman secara langsung akan memberikan sebuah pengalaman yang kelak akan dapat diimplementasikan dalam Berpikir kreatif dengan memberikan kebebasan dalam mengeksplorasi ide-ide akan memberikan tantangan bagi mahasiswa. Selain harus kreatif calon guru PAUD juga harus peka terhadap lingkungan. Kreativitas dengan memanfaatkan bahan-bahan bekas yang ada disekelilingnya akan lebih dapat dirasakan kebermanfaatannya secara langsung olehnya. Mahasiswa PG-PAUD akan mendapatkan pengalaman secara langsung bagaimana menjadi penggerak pendidikan yang berkelanjutan. Pengalaman secara langsung akan memberikan sebuah pengalaman yang kelak akan dapat diimplementasikan dalam rancangan pembelajarannya saat sudah benar-benar terjun menjadi seorang guru PAUD.

\section{METODOLOGI}

Penelitian ini merupakan penelitian deskriptif kualitatif, dimana peneliti ingin mengungkapkan proses mahasiswa dalam mengeksplorasi bahan bekas menjadi produk kreativitas. Subjek penelitian adalah mahasiswa PGPAUD Universitas PGRI Adi Buana Surabaya angkatan 2017 yang sedang menempuh mata kuliah Kreativitas dan Keberbakatan, berjumlah 16 orang. Prosedur penelitian ini terdiri dari tiga tahap sebagai berikut. Tahapan pertama yakni persiapan, dilanjutkan tahapan kedua pelaksanaan, dan tahap terakhir yaitu penulisan laporan. Skema prosedur penelitian tergambar sebagai berikut.

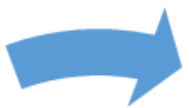

\section{PERSIAPAN}

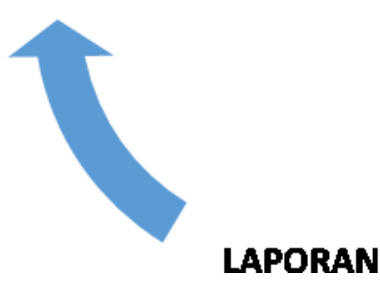

PELAKSANAAN

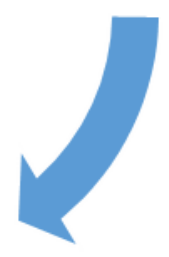

Uraian lengkap tahapan penelitian kemampuan mengeksplorasi bahan bekas pada mahasiswa PG-PAUD 
Jurnal HELPER, Vol 35 No 2 (2018) $01-04$

Bimbingan dan Konseling Universitas PGRI Adi Buana Surabaya

ISSN: 02162938

Universitas PGRI Adi Buana melalui project based learning sebagai berikut.

\section{Tahap Persiapan (Planning).}

Pada tahapan ini kegiatan yang dilakukan adalah a) merancang seluruh proyek, kegiatan dalam langkah ini adalah: mempersiapkan proyek, secara lebih rinci mencakup: pemberian informasi tujuan pembelajaran, guru menyampaikan fenomena nyata sebagai sumber masalah, pemotivasian dalam memunculkan masalah dan pembuatan proposal, b) mengorganisir pekerjaan, kegiatan dalam langkah ini adalah: merencanakan proyek, secara lebih rinci mencakup: mengorganisir kerjasama, memilih topik, memilih informasi terkait proyek, membuat prediksi, dan membuat desain investigasi.

\section{Tahap Pelaksanaan (Creating).}

Tahapan ini terdiri dari tiga tahap sebagai berikut. Tahap pertama peneliti berkolaborasi dengan mahasiswa saat proses perkuliahan, media yang digunakan ialah bahan bekas. Subjek yang digunakan dalam penelitian ini ialah 16 mahasiswa. Pada tahapan ini siswa mengembangkan gagasan-gagasan proyek, mengkombinasikan ide yang muncul dalam kelompok, dan membangun proyek. Tahap kedua ialah peneliti mengobservasi proses eksplorasi bahan bekas menjadi produk kreativitas selama 7 kali tatap muka. Isi dari tahap ini termasuk aktivitas pengembangan dan dokumentasi. Pada tahapan ini pula siswa menghasilkan suatu produk (artefak) yang nantinya akan dipresentasikan dalam kelas. Tahap ketiga ialah peneliti melakukan wawancara hasil pengolahan bahan bekas menjadi produk kreativitas terhadap subjek penelitian.

\section{Tahap Laporan (Processing).}

Tahapan ini meliputi presentasi proyek dan evaluasi. Pada presentasi proyek akan terjadi komunikasi secara aktual kreasi ataupun temuan dari investigasi kelompok, sedangkan pada tahapan evaluasi akan dilakukan refleksi terhadap hasil proyek, analisis dan evaluasi dari proses-proses belajar. Selanjutnya tahapan ini juga menyusun hasil penelitian, kemudian menganalisis dan menginterpretasikan. Hasil dari interpretasi diuraikan dalam bentuk laporan penelitian. Analisis data dalam penelitian ini menggunakan teknik deskriptif kualitatif dimana data berpikir kreatif dianalisis menurut Torrance

\section{HASIL PENELITIAN}

Penelitian ini dilaksanakan di Universitas PGRI Adi Buana Surabaya semester Genap 2018/2019 angkatan 2017 
dengan melibatkan 16 mahasiswa sebagai subjek penelitian. Hasil dari penelitian ini adalah kemampuan mahasiswa dalam mengekplorasi bahan bekas menjadi produk kreativitas dengan rentangan tinggi, sedang, rendah. Hasil penelitian menunjukkan bahwa secara keseluruhan Kemampuan Mengeksplorasi Bahan Bekas Pada Mahasiswa PGPAUD Melalui Project Based Learning masih dalam kategori sedang, hal tersebut dikarenakan setiap mahasiswa mempunyai kemampuan yang berbeda-beda dalam mengeksplorasi bahan bekas menjadi produk kreativitas

\section{KESIMPULAN}

Berdasarkan paparan hasil penelitian dan pembahasan maka dapat disimpulkan sebagai berikut Kemampuan Mengeksplorasi Bahan Bekas Pada Mahasiswa PGPAUD Melalui Project Based Learning masih dalam kategori sedang, hal tersebut dikarenakan setiap mahasiswa mempunyai kemampuan yang berbeda-beda dalam mengeksplorasi bahan bekas menjadi produk kreativitas.

\section{DAFTAR PUSTAKA}

Asrori, M. (2008). Psikologi

Pembelajaran. Bandung: Wacana Prima.

Bobbi, D., Mark, R., \& Sarah, S. (2001). Quantum Teaching. Bandung: Kaifa.

Djoko, W. A., \& Anies, L. (2017). Kompendium PAUD
Memahami PAUD Secara Singkat. (S. Eko, Ed.) (1st ed.). Jakarta: Prenadamedia Grup.

Elizabeth, H. (2013). Perkembangan Anak II (6th ed.). Erlangga.

John, S. (2007).

Perkembangan Anak. (H.

Wibi, Ed.) (12th ed.).

Jakarta: Erlangga. Johnson

B. Elaine. (2002).

Contextual Teaching \&

Learning. Bandung: MLC.

Mario, T. (2009). Guru

Super Indonesia. Jakarta:

Mario Teguh Publishing

House.

Mayesky Mary. (2012). creative activities for young children. (S. Linda, Ed.) (10th ed.).

Belmont: Wadsworth.

Rebecca, I., \& Raines, S. (2007). Creativity and the Arts with Young Children. (R. Serenka, Ed.) (2th ed.). 2007: Delmar Cengage Learning.

Sugiyono. (2010). Metode Penelitian Pendidikan Pendekatan Kuantitatif, Kualitatif dan R\&D (11th ed.). Bandung: Alfabeta. 